\title{
Limitations of Thailand's Participation in the Regional Cooperation of ASEAN Community
}

\author{
Zhiyuan Ren ${ }^{1, *}$ Zhaoyang Duan ${ }^{1}$ Shanshan Bao ${ }^{1}$ \\ ${ }^{1}$ Yunnan Chinese Language and Culture College, Yunnan Normal University, Kunming, Yunnan, China \\ *Corresponding author. Email: 380690719@qq.com
}

\begin{abstract}
This paper makes an in-depth analysis of Thailand's participation in ASEAN political, security and economic community. This paper argues that Thailand's political unrest has an impact on its cooperation with the ASEAN Political Community, some problems such as border and territorial disputes left over by history, terrorist threats and drug eradication threat its cooperation with the ASEAN Security Community and its economic cooperation with the ASEAN Economic Community is also limited by the lack of commodity competitiveness.
\end{abstract}

Keywords: ASEAN Community, Thailand, Regional cooperation.

\section{INTRODUCTION}

Thailand has played a positive role in promoting ASEAN's political, economic and security cooperation at various stages, which is obvious to all. However, due to its own environmental conditions, historical problems, and the need to safeguard national interests in the process of regional integration, Thailand also has some limitations in ASEAN political, economic, security and other cooperation, which has a negative impact on its participation in the process of regional integration.

\section{LIMITATIONS OF THAILAND'S PARTICIPATION IN THE POLITICAL COOPERATION OF ASEAN COMMUNITY}

\subsection{Domestic Politics Have Weakened Thailand's Influence in ASEAN}

Since the military coup of Thailand broke out on September 19, 2006, its role and influence in the process of ASEAN regional integration began to decline gradually. First, the political situation has weakened Thailand's leading role in ASEAN. Compared with the "economic community" proposed by Singapore, the "political security community" proposed by Indonesia, the "social and cultural community" proposed by the Philippines, and the ASEAN "10+3" advocated by Malaysia, Thailand seems silent. Second, the political turmoil has affected Thailand's political reputation in ASEAN. In July 2008, Thailand took over the rotating chairmanship of ASEAN from Singapore. Due to the influence of Thailand's political situation, the 14th ASEAN Summit scheduled to be held by Thailand in December 2008 had to be rescheduled and moved to another place. Besides, the 2009 ASEAN "10+3" and "10+6" Leaders' Meeting also failed to be held as scheduled due to the tense situation in Thailand. In April 2009, two leading international credit rating agencies Standard \& Poor's (S\&P) and Fitch (Fitch), successively downgraded Thailand's sovereign credit rating because of the unrest caused by the protests of the "Red Shirts". Fitch's downgrade of Thailand's sovereign credit rating, especially its foreign currency rating, marks Thailand's first such downgrade by Fitch since 1998 and the first foreign currency downgrade by an international credit rating agency since the 1997 financial crisis [1]. In March 2019, although the general election in Thailand has been preliminarily completed, the final official result of the election is not yet clear. Under the leadership of Prayuth Chan-ocha, Thailand has taken over the rotating chairmanship of ASEAN in 2019. In order to ensure the smooth convening of the ASEAN summit and avoid the domestic political situation as before, Thailand had to suggest that the ASEAN summit should be postponed from April 2019 to June. Due to the 
long-term political turmoil in Thailand, successive governments have struggled to keep ASEAN in their own hands, which weakens Thailand's leading role and international reputation in ASEAN, and restricts its development prospects in the process of ASEAN regional integration to a certain extent.

\subsection{The Identity of the "Peacekeeping Council" Cannot Support ASEAN's Various Cooperation}

The intensification of political parties and the popularization of political rights are the main characteristics of Thai politics, which makes Thai politics full of uncertainty caused by the tugs of war of power. In 2014, in order to improve the political situation, reform the political structure of the country and maintain the unity of all sectors of society, Thailand established the "National Council for Peace-keeping Order" (Peacekeeping Council). Prayuth Chan-ocha, commander of the Thai Army, was appointed by the royal family as the chairman was fully responsible for handling state affairs.

The "Peacekeeping Council" was entrusted with a mission at a critical and difficult moment. In terms of participating in ASEAN's political, economic and security cooperation, the Peacekeeping Council has actively hosted international conferences, made full use of the regional multilateral arena and put forward proposals to expand ASEAN's regionalism cooperation, vigorously advocate strengthening economic cooperation, infrastructure and connectivity construction, in order to revive Thailand's advantages, play the leading role, and promote economic development and cooperation in the ASEAN region so as to regain the dominant right and voice of regional development and strive to be a leader in the region. However, as Thailand has long been confined to domestic political struggles, it is difficult to change the harsh reality of "advance or retreat" in the short term. The proposal of the "Peacekeeping Council" to promote infrastructure construction and connectivity among countries on the Southeast Peninsula to promote trade, investment, the construction of the East-West Economic Corridor and the construction of border economic zones have failed to meet the expected goals. First of all, the "Peacekeeping Council" is only an interim government in nature, and its "legitimacy" status in Thailand and abroad is still in doubt. Its foreign policy will inevitably be transitional. If each Thai government cannot govern continuously, its policies will lack coherence and consistency. Although leaders and international (regional) organizations have basically recognized and accepted the diplomatic activities of the Prayuth government, at the same time, they have more or less distrust of the Thai government and are more cautious when cooperating with Thailand, which will inevitably affect the relations between Thailand and ASEAN member states. Second, uncertainties in the regional situation and the world economy have increased. At present, the overall development of the world economy is weak, with trade protectionism on the rise. In addition, the policy of the United States towards Southeast Asia is not clear, and the political development of Thailand is uncertain. Against this background, most ASEAN countries take a wait-and-see attitude towards Thailand and dare not carry out large-scale cooperation with it rashly[2]. Therefore, the awkward status of the "Peacekeeping Council" makes Thailand fall into a situation of lack of trust. All the member states take a cautious and wait-andsee attitude towards the ASEAN policy and cooperation proposed by Thailand, fearing that the "Peacekeeping Council" cannot ensure the continuity and consistency of Thailand in ASEAN cooperation for a long time.

\section{LIMITATIONS OF THAILAND'S PARTICIPATION IN THE SECURITY COOPERATION OF ASEAN COMMUNITY}

\subsection{Border and Territorial Disputes Have Seriously Affected Regional Peace and Stability and Relations Between Member States}

There are many contradictions and even conflicts caused by territorial disputes among ASEAN countries, which often lead to tension among member states, threaten ASEAN's regional interests and peace and stability, and seriously hinder ASEAN's regional integration process. In the initial stage of ASEAN Community development, various territorial disputes will multiply. As far as Thailand is concerned, the most intractable problem at present is to deal with the domestic ethnic division issue, the Southern Thailand issue and the territorial disputes between Thailand and its neighbors [3]. According to statistics, there have been 35 territorial disputes among ASEAN members since 1969 , of which only 14 have been settled peacefully and 6 have been submitted to the International Court of Justice. Thailand accounts 
for a third of the remaining 15 unresolved territorial disputes, involving all of its neighbors: its dispute with Laos over the Mekong, Demarcation of the Land Boundary between Thailand and Myanmar, Thailand and Cambodia land border demarcation and overlapping areas in the Gulf of Siam dispute, Disputes over demarcation of part of the border between Thailand and Malaysia, and Thailand's overlapping claims with Vietnam and Malaysia in the Gulf of Siam.

In recent years, the territorial and maritime disputes between Thailand and Cambodia have not been completely resolved, which does not roll out the possibility of new frictions and even border conflicts between the two countries in the future. The territorial issue is a sensitive issue in both Thailand and Cambodia, where nationalism is likely to inflame. Since the International Court of Justice ruled against Thailand, activists and media in Thailand are frustrated and are constantly following every move of the Thai government and army on the land around the Preah Vihear Temple on the border between the two countries. Any "compromise" action of the Thai army will be magnified and condemned by the media and public opinion. Ouila, a Thai who was jailed in Cambodia for "trespassing" at the Preah Vihear Temple, has become a celebrity in Thailand, with many admiring and trying to emulate his "patriotic actions" to keep the country united. Tensions flared again in the Preah Vihear area in early January 2015 because Thailand deployed more than 200 troops to the area after Cambodia built a road in the area late last year, which Thailand considers neutral. In December 2015, when Cambodian Prime Minister Hun Sen visited Thailand, the Prayuth government made special arrangements to keep Ouila under control to avoid trouble, but this was only a temporary move by the Thai government [4].

On the whole, the long-term troubled and often sudden territorial disputes have caused two major influences on Thailand's participation in ASEAN cooperation. First of all, territorial disputes have led to tensions between Thailand and neighboring countries, hindering the process of ASEAN regional integration. In order to safeguard national interests and territorial and sovereign integrity, territorial disputes cannot be peacefully and thoroughly resolved in a short period of time. The friendly and cooperative relations that Thailand has built and accumulated with painstaking efforts over the years may be destroyed, and it thus would lose the support of neighboring countries, and the ASEAN connectivity and border security management cooperation that Thailand advocates cannot continue to be carried out. Secondly, the territorial dispute made Thailand take the lead in violating and destroying ASEAN's basic principles of peaceful settlement of disputes. In a territorial dispute between Thailand and Cambodia, the two sides mobilized troops to confront each other in a disputed area, which eventually led to a military skirmish. Both Thailand and Cambodia have violated the basic principles of the ASEAN Charter on renouncing attacks and relying on peaceful settlement of disputes. Thus, it has been proven that regional peace and national security become the fish and bear's paw, and regional peace efforts often have to give way to national security interests [5]. Thailand is far more exposed to such a potential crisis than any other country. The border territory issue will profoundly affect the cooperation between Thailand and ASEAN member states in a certain period of time.

\subsection{Non-traditional Security Issues Are Becoming Increasingly Serious}

The main terrorist threat to Thailand comes from attacks carried out by Muslim extremists in southern Thailand. According to the Institute for Economics and Peace's "Global Terror Index" for 2015, Thailand ranks 10th at the high end of the scale. Yala, Pattani, Narathiwat and Songkhla in southern Thailand are the areas where Muslim separatist activities are most rampant. Since 2015, Thailand has experienced an extremely rare threat of international terrorism, with the bombing of the Erawan Shrine in Bangkok and the attempted infiltration of Islamic State terrorists as the major landmarks. As of April 2016, extremist terrorist activities in southern Thailand had left more than 6,500 people dead and more than 10,000 injured, most of them civilians. The Thai army says it will push ahead, even if current negotiations with Muslims in the south are difficult. Some analysts say that if the Thai government does not allow a high degree of autonomy to parts of the south, it will be difficult for local armed groups to give up their fight, and stability will be like a castle in the air. What is more serious is that many terrorists communicate in non-common language or code with the help of modern communication means such as network and mobile phone, making it difficult to detect or prevent their terrorist planning activities. If domestic and foreign terrorists interact with each other, Thailand's anti-terrorism situation will become more serious. Judging from the current developments, it is difficult for Thailand to 
completely solve the terrorist threat in the southern border areas in the short term, as the "Peacekeeping Council", busy with political stabilization, has not had time to devise and implement a lasting Muslim policy in the South. Crucially, the two sides could not agree on a "high degree of autonomy" for Muslims in the south. Therefore, the development trend of terrorism in Thailand will seriously threaten the political, economic and security environment of Thailand. No matter in attracting foreign investment, developing tourism industry, and implementing ASEAN connectivity, the terrorist activities in the southern border areas of Thailand have greatly restricted Thailand from playing its due role, and even if the cooperation projects are completed as expected, it is difficult to guarantee their safe development.

In addition to dealing with terrorism, the daunting task of combating narcotics is another important non-traditional security issue Thailand needs to face. In 2017, the National Narcotics Commission of Thailand and the Thai Ministry of Defense jointly released a survey report on the "Status of Drug Problem in Thailand". The report pointed out that 90 percent of the drugs in Thailand are mainly from abroad, and Thailand has become a major drug trafficking target country and a "transit country" for drugs from all over the world. Among the 81983 villages and communities in Thailand, 24,282 villages and communities have drug problems, accounting for about 30 percent of the total number of villages and communities in Thailand. The main drugs are amphetamines, methamphetamine, marijuana, heroin and cocaine. The high, middle and low prices of illegal drugs in Thailand all showed an overall trend of decline, which indicated that the quantity of drugs in Thailand was higher than the market demand. In addition, the trafficking mode also began to rely on covert ways like the network and email, etc. The number of drug users is increasing and tends to be younger. According to statistics, in 2016, the age of drug users in Thailand ranged from 12 to 65 years old, accounting for about $66.5 \%$ of the total number of drug users, and $40 \%$ of them were under the age of 25. Although Thailand has been very strict in cracking down on drugs, and has formulated many anti-drug policies and measures, and carried out a number of anti-drug actions, it has always been difficult to get practical results. With the development of connectivity and cooperation among ASEAN countries, Thailand will face a more arduous task of combating drugs. The circulation of drugs will become more difficult to control, and its obstacles to social stability and economic development will become more severe. Transnational crimes caused by the drug problem will also have a profound impact on Thailand's national image in ASEAN.

\section{LIMITATIONS OF THAILAND'S PARTICIPATION IN THE ECONOMIC COOPERATION OF ASEAN COMMUNITY}

As an economic power in the ASEAN Community, Thailand has played a pivotal role in guiding and promoting the process of ASEAN regional economic integration, and its own economic development is also at the forefront of ASEAN. But with the development of ASEAN regional economic integration gradually deepening, Thailand also gradually showed the problem of insufficient commodity competitiveness in the construction of ASEAN community.

The ASEAN countries are rich in natural resources, and most of them are "export-oriented" economies, but the problem of product homogeneity is increasingly prominent. With the rapid development of ASEAN single market, Thailand's low value-added primary commodities will be the first to be affected by the competition and impact of other ASEAN countries. The interacting state and market are the main driving force for the development of ASEAN economic cooperation, as well as the main restraining factor [6]. ASEAN countries not only produce similar products, but also export products to basically the same areas, mainly Europe, North America, Japan and China, so that the export trade of each country is highly competitive. According to the theory of international trade, if the economies of two countries or regions are highly complementary, the flow of products and production factors will be easier; otherwise, it will cause obstacles. Therefore, as ASEAN member countries have strong economic competitiveness, the free flow of production factors in the regional market will be hindered [7]. According to the statistics of ASEAN, from 1993 to 2001, exports within the ASEAN region accounted for $21 \%$ to $25 \%$ of ASEAN's export market, and the remaining $75-80 \%$ were mainly exports to countries and regions outside the region. Among those countries and regions outside the region, the United States, Japan and the European Union accounted for $40 \%$ to $50 \%$ [8]. At present, Thailand is facing many challenges, the past economic development model is no longer 
applicable. The rising cost of labor and an increasingly restrictive legal environment have made it impossible for some industries that used to drive economic growth to survive [9]. The electronics, electrical appliances and textile and apparel industries, which account for more than $30 \%$ of Thailand's exports, may not be able to maintain their competitiveness, and some of those companies are moving to other countries, including Vietnam, to take advantage of cheaper labor. While the Thai government seeks new ideas for industrial development, it should also address the immediate problems, engage with stakeholders and develop exit strategies for these industries [10].

Under the conditions of similar export commodities, trade markets and tariffs, relatively high additional labor costs and production costs needed by commodities with low added value in Thailand, naturally cause a gradual decline in its commodity competitiveness. In order to cope with such development and changes, Thailand on the one hand put forward the "Thailand 4.0" strategy, trying to develop high value-added industries through innovation and technology application, change the economic structure, promote economic transformation, and get rid of the status quo of trade competition. However, whether Thailand's industrial upgrading and transformation can be smoothly implemented and completed in the short term will be a severe test for Thailand. On the other hand, Thailand is actively exploring new export markets for commodity trade and strengthening bilateral trade cooperation with other countries. Although it is the foreseeable way for the regional economic integration of the whole East Asia including ASEAN to put equal importance on both bilateral trade and multilateral trade, focusing on bilateral trade when multilateral trade is being checked and promoting multilateral trade with the progress in bilateral trade [11]. However, under the trend of ASEAN countries competing with each other and competing to develop economic relations outside the region, ASEAN did not get out of the predicament of marginal zone development economically. On the one hand, ASEAN has introduced different framework agreements, work programs and master plans at different stages to highlight the central role of ASEAN, strengthen intra-regional trade and investment, and get rid of dependence on external powers. On the other hand, ASEAN member states are not willing to follow the principle of putting "ASEAN as the center" completely, but compete to cooperate with external powers[12]. Therefore, in the process of participating in regional economic integration, ASEAN member states cannot guarantee the consistent national interests of all member states. In order to safeguard national interests, Thailand will face a difficult dilemma in choosing to pay attention to intra-regional or extra-regional economic cooperation.

\section{CONCLUSION}

To sum up, Thailand's limitations in participating in ASEAN's political, economic and security cooperation are mainly from its own environmental conditions and the negative impact brought by its participation in the integration process. In terms of its own factors, the political situation of Thailand has a very important impact on its participation in ASEAN political, economic and security cooperation, which determines the strength of Thailand's role in the ASEAN integration construction, as well as the implementation progress and effectiveness of the regional integration construction. Besides, Thailand is also the country with the most border disputes among ASEAN members. Most of the territorial issues that have not been satisfyingly resolved have led to certain suspicion and precaution among member states, and become potential threats to the construction of the ASEAN political and security community, which is not conducive to the smooth development of political, economic and security cooperation between Thailand and member states. In the interaction of participating in ASEAN's political, economic and security cooperation, Thailand will face more prominent and serious problems such as non-traditional security and lack of commodity competitiveness, which will not only affect Thailand's cooperation with other member countries, but also expand its impact to the construction and development of the whole region.

\section{AUTHORS' CONTRIBUTIONS}

Zhiyuan Ren wrote the manuscript, Zhaoyang Duan contributed to revising and editing, Shanshan Bao analysed data.

\section{REFERENCES}

[1] Chen Hongsheng, Thailand: Retrospect of Situation in 2009 and Prospect of Which in 2010. Around Southeast Asia, No.5, 2010, p. 23. (in Chinese) 
[2] Zhuang Guoguo, Lin Hongyu, Liu Wenzheng. Blue Book on Thailand (2018), Beijing: Social Sciences Academic Press, 2019, pp. 319325.(in Chinese)

[3] Liang Xia. The Cognition of Some Thai Political Dignitaries and Experts on Thailand's Joining the ASEAN Community. Southeast Asian Studies, 2015, 1, page 144. (in Chinese)

[4] Zhuang Guoguo, Liu Wenzheng, Zhang Yudong. Blue Book on Thailand (2016), Beijing: Social Sciences Academic Press, 2016, pp. 153-154. (in Chinese)

[5] Wang Zichang, Guo Youxin, "National Interest VS. Regional Interest: Political Economics of ASEAN Cooperation", Beijing: World Knowledge Press, 2005, p. 80. (in Chinese)

[6] Lu Guangsheng. ASEAN'S Economic Cooperation: A Regionalism Perspective. Shanghai: Fudan University, 2006, pp. 183. (in Chinese)

[7] He Ai. On Asian Economic Community: Necessity, Feasibility and Challenges. Southeast Asian Studies, No.4, 2007, pp. 39. (in Chinese)

[8] Wang Zhengyi, "ASEAN in 50 Years: Is It Out of the Dilemma of Marginal Development? - Reflections on the" ASEAN Way "and "ASEAN as the Center", World Politics Studies, 2018, No. 1, p34. (in Chinese)

[9] Liang Xia. The Cognition of Some Thai Political Dignitaries and Experts on Thailand's Joining the ASEAN Community. Southeast Asian Studies, 2015, 1, page p41. (in Chinese)

[10] Suthad Setboonsarng (2016). A Strategic Approach for the Next Era of ASEAN Economic Cooperation, Bangkok: The Department of ASEAN Affairs, Ministry of Foreign Affairs of the Kingdom of Thailand, pp71.

[11] Cao Yunhua, Zhu Youen: ASEAN's Strategy for the Integration of Regional Economic, Journal of Social Sciences (Humanities and Social Sciences), 2015 (1), p4. (in Chinese)

[12] Wang Zhengyi, "ASEAN in 50 Years: Is It Out of the Dilemma of Marginal Development? — Reflections on the" ASEAN Way "and
"ASEAN as the Center", World Politics Studies, 2018, No. 1, p39. (in Chinese) 